\title{
THE VIRGINIA CAVE PROTECTION ACT: A REVIEW (1966-2009)
}

\author{
THOMAS LERA \\ Chairman, Virginia Cave Board, 217 Governor Street, 3rd Floor, Richmond, VA 23219, frontier2@erols.com
}

\begin{abstract}
The Virginia Cave Protection Act was first ratified in 1966, with a major revision in 1979, yet Virginia cave and karst resources are still threatened by vandalism, pollution, and poorly planned development. As public interest in outdoor recreation continues to grow and land development accelerates in the Appalachian Valley and Ridge Province west of the Blue Ridge Mountains, increased pressure will be put on Virginia's limited and fragile cave resources. Over the past thirty years, there have been many important court cases in Virginia, as well as countless state and federal actions. The difficulty of apprehension and prosecution of vandals demonstrates the inadequacy of current penalties. More prosecutions and harsher penalties will invariably serve as a deterrent to future potential vandals. Complex state projects, like highway widening and the construction of new prisons and airports, put additional pressure on karst areas. In order to preserve the unique educational, recreational, scientific, historic, and economic values of Virginia caves and karst, the Virginia Cave Board has been authorized to safeguard these resources.
\end{abstract}

DOI: $10.4311 /$ jcks20081sc0027

\section{INTRODUCTION}

The first Virginia Cave Protection Act became law on March 2, 1966, when House Bill 24 became Section 18.1175.1 of the 1950 Code of Virginia. It was the clear the intention of the legislators to protect Virginia Cave resources, especially those found in commercial caverns bringing tourist dollars to the State. With the 1975 recodification of Title 18, the Cave Protection Act was moved to Section 18.2-142 under "Damaging Caverns or Caves" and contained two parts:

(a) It shall be unlawful for any person, without the prior permission of the owner, to willfully and knowingly, break off, crack, carve upon, write or otherwise mark upon, or in any manner destroy, mutilate, injure, deface, mar or harm any natural material found within any cave or cavern, such as stalactites, stalagmites, helictites, anthodites, gypsum flowers or needles, flowstone, draperies, columns, or other similar crystalline mineral formations or otherwise; to kill, harm or disturb plant or animal life found therein; to discard litter or refuse therein, or; otherwise disturb or alter the natural condition of such cave or cavern; or break, force tamper with, remove, or otherwise disturb a lock, gate, door or other structure or obstruction designed to prevent entrance to a cave or cavern, without the permission of the owner thereof, whether or not entrance is gained.

(b) Any violation of this section shall be punished as a Class-3 Misdemeanor. [Changed in 1975 from a fine not exceeding \$500 or confinement in jail not exceeding 12 months.]

In January 1978, members of the Virginia Region of the National Speleological Society, alarmed by the accelerating degradation of Virginia's cave resources, asked Representative Bill Axselle of Richmond to introduce legislation into the Virginia General Assembly that would create a commission to study the conservation of cave resources. An amended House Joint Resolution No. 10 was passed, and an eleven-member Commission on the Conservation of Caves was appointed by Governor John Dalton to "study all problems incidental to cave use, protection, and conservation in Virginia." The members of this Commission were John Wilson, Chairman, John Holsinger, Vice-Chairman, Evelyn Bradshaw, Secretary-Treasurer, Robert Anderson, Roy Clark, Wayne Clark, Robert Custard, Henry T.N. Graves, John Kettlewell, Philip Lucas, and Virginia Tipton.

In December 1978, the commission completed its study and submitted its findings to the governor and general assembly (Commonwealth of Virginia, 1979). This report documented the rapid deterioration of Virginia's caves as geological, archaeological, biological, recreational, and educational resources. The commission recommended that an inventory of archaeological resources in Virginia caves be made, a permanent commission be created, and a new Cave Protection Act giving broader protection to cave resources be enacted (Department of Conservation and Economic Development, 1979).

The 1979 session of the general assembly, responding to the recommendations of the Commission on the Conservation of Caves, created the Virginia Cave Commission and enacted a new comprehensive Cave Protection Act with two basic objectives. The first was to protect Virginia cave resources from vandalism and degradation; the second, to protect the cave owner's property interests. Violations of the act were designated as class-3 misdemeanors, punishable by a fine of up to five hundred dollars.

Under the provisions of this new law it is illegal to remove, mar, or otherwise disturb any natural mineral formation or sedimentary deposit in any cave without the 
owner's express, prior, written permission. (The 1975 act had not required that permission be obtained in writing.) Although collection of mineral specimens is not completely prohibited, it was the intent of the commission that future collection be as minimal, selective, and scientific as possible. The act was designed to preserve the beauty of Virginia caves and prevent them from being destroyed by indiscriminate collection or vandalism. It also is illegal to sell, or export for sale, speleothems (mineral formations or deposits found in caves). The general assembly felt that by eliminating the market, much of the incentive for theft would also be eliminated.

The commission's report stressed that caves are unique natural laboratories for the investigation of biological processes. Natural organisms found in caves live in fragile environments where even small man-made disturbances can produce major changes in cave ecosystems. Many of the more than two hundred animal species found in Virginia caves are restricted to small geographic areas, occur in very small populations, and have been placed on the Endangered Species List. The Cave Protection Act, therefore, prohibits disturbing or harming any cave organism.

The pollution of groundwater, as a result of the dumping of garbage, sewage, dead farm animals, and toxic wastes into caves and sinkholes, had been a problem in the state. It now is illegal to dump any litter, waste material, or toxic substance in any cave without the express, prior, written permission of the owner.

The new act protects archaeological resources by requiring a permit from the Virginia Historic Landmarks Commission and written permission from the cave owner to excavate, remove, or disturb any fossils, historical artifacts, or prehistoric animals. It also protects gates, locks, and other barriers designed by the cave owner to prevent or to control access to the cave. It is illegal to break, force, or tamper with these barriers or to remove or deface any sign posted by the owner. The cave owner is also exempted from liability for any injury sustained by others in the cave as long as an admission fee was not charged.

\section{Legislative History of the Virginia Cave Protection Act}

A brief summary of the legislative history of the Cave Protection Act through 1985:

House Bill 24 created Section 18.1-175.1 "Damaging Caverns or Caves" on March 2, 1966.

"Damaging Caverns or Caves" was moved to 18.2-142.

House Bill No. 1800, introduced by Representative Axselle to create a Virginia Cave Commission, became law (Title 9 Chapter 24.1 Section 9-152.1 through 152.5) on October 28, 1978.

House Bill No. 1220, introduced by Representative Axselle to create the Virginia Cave Protection Act, became law (Title 10 Chapter 12.2 Section 10-150.11 through 10150.18) on March 15, 1979. Section 18.2-142 was repealed.

House Bill No. 240, introduced by Representatives Murray, Giesen, Axelle, and Michie, reestablished the Cave Commission and amended its powers and duties (January 21, 1980).

House Bill No. 92, introduced by Murray, Axselle, and Van Yahres changed vandalism, pollution, and the sale of speleothems from a class-3 misdemeanor to a class-1 misdemeanor and added a section on paleontology, 1982. (The penalty for a class-1 misdemeanor is a fine not exceeding $\$ 2,500$ or confinement in jail not exceeding 12 months or both.)

A name change from Virginia Cave Commission to Virginia Cave Board was effective July 1, 1985.

The Virginia Cave Protection Act was amended several more times, as late as 1989, and now defines the Virginia Cave Board and its powers and duties, provides for permits for excavation and scientific investigations, establishes penalties for vandalism, pollution, disturbances, and sale of speleothems, and reduces the liability of land owners.

\section{Examples of CAve BoARd Actions}

\section{VANDALISM}

The Virginia Cave Board (née Cave Commission) has been involved in several court cases regarding vandalism and has worked with various communities to protect cave resources. In 1981, local students illegally entered the fenced Barterbrook Spring Cave. The owner had the students arrested, but, rather than go to court, their parents paid for a new fence. (Virginia Cave Commission Minutes, March 29, 1981. Copies of Commission and Board minutes can be obtained from the Virginia Department of Conservation and Recreation, 217 Governor Street, 3rd Floor, Richmond, VA 23219.)

In another case, students from James Madison University who had removed speleothems from Fountain Cave argued in their defense they did not know it was illegal because there was no sign at the cave. They were sentenced to complete a special project at the university to benefit caves, including publication of an article in the JMU newspaper about the new Cave Protection Act and the importance of preventing cave vandalism (Virginia Cave Commission, December 6, 1981).

In 1984, a man was apprehended inside Perkins Cave after he had damaged the gate and entered the cave without authorization. The judge sentenced him to ten hours of public service installing cave protection signs in lieu of a \$100 fine (Virginia Cave Commission, June 2, 1984).

In southwestern Virginia, two students allegedly entered a cave to collect speleothems for a science project. They saw a sign that said in large letters, "THIS CAVE is protected." They left, found another cave without a sign, and collected their speleothems. Again, the judge sentenced them to community service. As a result of this case, the 
Virginia Cave Commission changed its signs from "THIS CAVE in protected" to read "ALL CAVES are protected" (Virginia Cave Commission, June 2, 1984).

In the fall of 1985, there was a break-in at Madison's Saltpetre Cave in Augusta County. The vandals were identified, the cave owner prosecuted, and they were sentenced to twenty hours of community service (Virginia Cave Board, May 10, 1986).

Commercial caves have also had their share of vandalism. In 1981, Grand Caverns was closed for two weeks when six Boy Scouts, camping nearby with their troop from Silver Spring, Maryland, vandalized the cave. They were arrested, released on $\$ 500$ bond, and sentenced to community service after their hearing. Massanutten Caverns had its steel-plated door smashed in, but there were no arrests (Collins, 1981).

Many, but not all, of the cases involved lack of vandalism-deterrent signage. Nevertheless, out of 370 significant caves in Virginia, only 100 have cave-protection warning signs today.

\section{Project Review}

Between 1981 and 1984, the Commission became involved in a long, drawn-out discourse with the Town of Grottoes, via letters, meetings and hearings, regarding a proposed water tank and pipeline on Cave Hill. Planned blasting and other construction activities, as well as possible future failure of the water tank, raised many concerns, including potential damage to speleothems in Grand Caverns, collapse of cavities, pollution and siltation of the Cave Hill Aquifer, or changes in groundwater flow. The number-one concern was the potential impact on the Madison Cave Isopod, Antrolana lira, which was on the Endangered Species List of the Fish and Wildlife Service. During this same review period, a sinkhole was inadvertently filled and Federal funding was delayed. Additional studies were conducted, and as a result, all concerns of the Cave Commission were addressed by the town and their engineers and the water tank was built (Shetterly, 1983; 1984).

\section{DeEd INTERPRETATION}

In 1985, a group of students and their professor from Lincoln Memorial University (LMU) in Tennessee were photographed removing speleothems at Cudjo's Cave (Home Daily of the Cumberlands, Middlesboro, Kentucky, November 18, 1985), resulting in a lengthy legal discussion over exceptions in the property deed. On April 3, 1947, the property was deeded from LMU to the Commonwealth of Virginia (Commonwealth), with two relevant exceptions. The first reserved for the grantor (LMU) a parcel of about ten acres that included the entrance to Cudjo's Cave. The second exception reserved for LMU the exclusive right to operate and use Cudjo's Cave, even though the cave extended beyond the ten-acre parcel reserved by the first exception. By a second deed, on May 4, 1950, LMU granted the Commonwealth the ten-acre tract reserved by the first exception to the 1947 deed, and expressly released any further right, title and interest to the cave based on its previous title to the reserved tract. However, in giving up its title to the property, LMU reserved the right to "explore, use, occupy, maintain, develop, operate, and exhibit for profit or otherwise," the caves underlying the tract. On December 1, 1953, the Commonwealth deeded the property, subject to LMU's easement, to the United States for inclusion in Cumberland Gap National Historic Park. The easement reserved by LMU was conditioned expressly upon the fact the property was to be included in the National Historic Park. LMU agreed to the 1950 deed as a condition of the exclusive right to operate and exhibit the cave. The Commonwealth's 1953 deed to the U.S. included the easement reserved by LMU.

In letters received by the Virginia Cave Board, one attorney stated,

Applying the ordinary rules of construction to the lease terms in question, it appears that the intent of the parties was to transfer all title and rights to the cave to the Commonwealth, subject to the easement reserved to LMU to explore, use, occupy, maintain, develop, operate and exhibit the cave.

The easement, in turn, is limited by the language requiring compliance with all National Park Service (NPS) requirements and regulations, as well as by language indicating a clear intent that the cave be used in a manner consistent with park objectives. Reading the terms together, the lease ensures that LMU's exclusive rights, as set out therein, are not to be barred by the fact that the cave is on National Park property (e.g., LMU does not have to allow public access, cannot be prevented from entering or using the cave, and need not compete with other concessionaires for the privilege of showing the cave for profit). They cannot, however, undertake those activities in a way that would damage, destroy or deface the caves in a manner contrary to park regulations.

This is the only interpretation consistent with the fact that the NPS owns the cave, while LMU owns only an easement giving it certain access and use rights. This is not a typical holding case where the original owner retains the fee or other estate in the land. There is nothing in the language of the easement indicating the property owner intended to allow the easement holder to damage or deface its property, and courts will not construe an easement in such fashion absent express language.

In sum, the deeds construed together require LMU to comply with all NPS cave protection regulations, including 36 C.F.R. § 2.1(a)(1)(iv), which prohibits possessing, destroying, impairing, defacing, removing or disturbing any cave formation or part thereof. The National Park Service has full authority to enforce those regulations against LMU consistent with the term of the deed. (Personal Correspondence from Timothy G. Hayes, Thomas and Fiske, P.C., March 25, 1986.)

Another attorney, Linda Loomis, wrote, "In this opinion, if the language of the deeds is controlling, the National Park Service does not have the authority to prevent resource removal. In brief, the deed granting the land to the United States Government references specific exemptions that benefit the grantor and former grantors of the property. Among those benefits is the use and exploitation of the cave. The language is broad enough to be interpreted to allow the removal of speleothems." 
(Personal Correspondence from Linda Loomis, National Parks and Conservation Association, February 24, 1986.)

It was clear to the Virginia Cave Board that, with exceptions, land deeds to the United States needed to be clearly understood before the Federal Government and the Commonwealth of Virginia could consider enforcement actions (Virginia Cave Board, January 18, 1986).

\section{Native American Burial Sites}

Bull Thistle Cave, the best preserved example of a burial-pit cave known in southwestern Virginia and listed in the National Register of Historic Places, was used by Native Americans for the burial of their dead during the Late Woodland Period (A.D. 900-1700) and contained archaeological remains in an excellent state of preservation. At least eleven individuals were represented among the bones exposed on the surface of the cave. The structure of the undisturbed talus cone below the pit entrance suggested more human remains and artifacts were probably buried there. Further scientific study of the cave deposits yielded important new information about the paleo-demographic characteristics and cultural practices of the Virginia Native Americans. The removal of remains from the cave was covered under Section 10.1-1003 in the archaeological section of the act, which resulted in the development of a management plan (Virginia Cave Board, September 20, 1986).

In August 2001, there was a break-in at Adams Cave, and human remains were removed. Local students were apprehended, and each was sentenced to ten hours community service (Virginia Cave Board, September 8, 2001).

In 2002, Native American remains removed for research purposes from Bone Cave in Lee County were re-interred at a site in Amherst County on land owned by the Monacan Indian Nation. Unexcavated remains are still in the significant and protected Bone Cave (Virginia Cave Board, November 23, 2002).

\section{ENDANGERED SPECIES}

In 1990, it was discovered that the Thompson Cedar Creek and Batie Creek watersheds in the Cedars Karst Area in Lee County had been polluted for more than three years with sawdust debris dumped by the Russell Lumber Company. The sawdust had accumulated in immense ridges 20 to 30 feet deep and 200 feet across, and acres of forest were covered with it. Surface water had become a black, viscous flow that was sinking into Thompson Cedar Creek and eventually the Powell River.

The caves of Lee County host a diverse and abundant fauna of cave-adapted invertebrates. Among them is Thompson Cedar Cave, where in the 1960s cave biologists John Holsinger and David Culver first discovered the Lee County Cave isopod, Lirceus usdagalun (Virginia Cave Board, June 9, 1990). Batie Creek was included on EPA's 303(d) list of impaired streams, and through the combined efforts of the Virginia Department of Conservation and Recreation, the Virginia Department of Mines, Minerals and Energy, the U.S. Fish and Wildlife Service, the Tennessee Valley Authority, the Curtis Russell Lumber Company, and the Cave Conservancy of the Virginias a recovery plan was developed. By 2005, the restoration of the Batie Creek watershed was complete. Accumulations of sawdust that had generated toxic leachate were removed and mixed with lime and fertilizer as a beneficial soil additive on nearby coal-mine-reclamation projects. Dissolved oxygen levels that had been near zero returned to normal levels. The Lee County isopod, Lirceus usdagalun, listed as endangered due to its extirpation from the cave in the late 1980's, recovered, although not to pre-impairment levels (Virginia Cave Board, March 19, 2005).

A new airport and a prison were planned for Lee County. These projects impacted significant biological resources, including an endemic millipede, several rare cave invertebrates, and rare plants, including a new species of clover found only in Virginia. The Virginia Cave Board wrote letters to the County Board and held meetings, resulting in the airport expansion but not the construction of the prison.

In June 1993, the board recommended a change in the proposed right-of-way for Route 58 in the vicinity of Young-Fugate Cave. With over 5,800 feet of surveyed passages, this cave is considered to be biologically, geologically, and hydrologically significant. A number of rare cave invertebrates, including the trechine beetle Pseudanophthalmus holsingeri, a dipluran Litocampa cooki, two aquatic crustaceans, and the gray bat, Myotis grisescens, have been noted there. The proposed right-ofway could well have led to future subsidence and eventual collapse of the roadbed into the subterranean passages. The result of numerous meetings was a rerouting of the right-of-way (Virginia Cave Board, June 19, 1993).

In 2007, Rocky Hollow Cave, located on the west slope of Powell Mountain and home to the endangered Indiana bat, Myotis sodalis, was vandalized. A gate installed at the cave entrance by the U.S. Forest Service in the late 1990s to protect hibernating Indiana-bat populations was breeched via a tunnel near the western end of the cave entrance. Inside were numerous patches of graffiti, including a date and several names in pink, white, and orange paint. Assuming the May 28, 2006, graffiti date was correct, it is unlikely the visit by the vandals caused any disruption or negative impact to the Indiana bat, as it was well past the winter hibernation period. Nevertheless, the Virginia Cave Board requested the assistance of the Wise County Sheriff in apprehending the perpetrators. One individual was apprehended, and based on the recommendation of the board, was ordered by the judge to clean up the graffiti, which resulted in ten hours of community service. Of note, when undertaking an enforcement action, the statute of limitations must always be considered. In Virginia, this statute is one year (Virginia Cave Board, March 24, 2007). 
Table 1. State-owned caves.

\begin{tabular}{lc}
\hline State Agency & $\begin{array}{c}\text { Number of Caves } \\
\text { Owned }\end{array}$ \\
\hline Department of Transportation & 75 \\
Department of Game and Inland & 53 \\
$\quad$ Fisheries & 9 \\
Natural Tunnel State Park & 6 \\
Department of Conservation and & 5 \\
$\quad$ Recreation & 4 \\
Commonwealth of Virginia & \\
New River Trail State Park & 3 \\
New Market Battlefield State Historic & 1 \\
$\quad$ Park & 156 \\
Virginia Polytechnic Institute & \\
Total &
\end{tabular}

Source: Virginia Speleological Survey Data Files, December 2007

\section{OTHER ACTIONS}

The Virginia Speleological Survey, on behalf of the Virginia Cave Board, now gathers and maintains an informational and survey database on Virginia caves.

The board proposed the Virginia big-eared bat as an ideal candidate, because of its name and its status as a federally endangered species, for educating Virginian residents about caves and the animals that inhabit them. Virginia Delegate Jackie T. Stump filed House Bill No. 2579 on January 12, 2005. On February 26, after being approved in both the House of Delegates and the Senate, the bill was signed by the Speaker of the House and the President of the Senate. On March 22, 2005, Governor Marc Warner signed the legislation designating the Virginia big-eared bat (Corynorhinus townsendii virginianus) as the official state bat of the Commonwealth of Virginia, effective July 1, 2005. The cave board continues to work with various state departments on environmental reviews and has participated in discussions on state regulations regarding caves and karst and the importance of their protection. The board has also worked with the Department of Historic Resources in granting permits for excavation and removal of archaeological, paleontological, prehistoric, and historic features in caves; worked with the Virginia Department of Transportation, the largest manager of state-owned caves, on the widening of state highways and the gating of significant caves; and worked with the Virginia Natural Area Program and Department of Game and Inland Fisheries on preparing management plans for state-owned caves (see Table 1). Several new species have been identified and listed on both the federal and state endangered-species lists. Board members Dr. John Holsinger and Dr. David Culver reported that the Department of Conservation and Recreation's Natural Heritage Program has recommended to the Virginia Department of Agriculture and Consumer Services that two species of cave beetle be added to the Virginia
Endangered Species List under the Virginia Endangered Plant and Insect Act of 1979. The board has suggested that the common name of the mud-dwelling cave beetle be changed to Maddens Cave beetle, and the common name of the thin-neck cave beetle be changed to Hupp's Hill cave beetle (Virginia Cave Board, September 16, 2006).

Ed Wallingford, Virginia Department of Transportation Hazardous Materials Program Manager, and Mark Nelson, the EPA Region III Underground Injection Control (UIC) Program Manager, concurred in correspondence with Department of Conservation and Recreation staff, that only sinkholes whose throats had been significantly modified to accept stormwater runoff were to be registered as Class V Injection wells by the EPA. However, in further conversations with the EPA, UIC staff revealed that Region IV employed a more inclusive definition of Class V injection wells to include any sinkhole to which runoff from converted land has been diverted (Virginia Cave Board, December 4, 2004).

State funding continues to be available for the various Virginia Agricultural Best Management Practices (BMPs). Efforts are underway to inform Virginia landowners about available cost-share and tax-credit opportunities through the programs. This cost-share program is funded through the State Water Quality Improvement Act and is administered by the Virginia Department of Conservation and Recreation through local Soil and Water Conservation Districts. The Agricultural Sinkhole Protection BMP (WQ11) will pay $75 \%$ of the cost of debris removal up to $\$ 2,500$. In addition to the cost-share payment, the program allows for a tax credit of " $25 \%$ of the total eligible cost, not to exceed $\$ 17,500$." Sinkholes with streams that flow into them are given priority under the program (Fagan and Orndorff, 2002; Virginia Cave Board minutes, December 3, 2005).

\section{Conclusion}

It has been 30 years since the 1979 act became law, and the importance of the confidentiality of significant cave locations and the difficulty of apprehending vandals continue to be addressed by the Virginia Cave Board. The prosecution of vandals demonstrates the inadequacy of current penalties. The Virginia Cave Protection Act should be amended to allow prosecutors to choose between a misdemeanor and a felony charge, similar to the Federal Cave Resource Protection Act. More prosecutions and harsher penalties will invariably serve as a deterrent to future potential vandals (Kramer, 2003).

Virginia cave resources continue to be threatened by vandalism, pollution, and poorly planned development. Unfortunately, many cave owners remain unaware of the immense scientific, historic, and economic value of the unique nonrenewable cave resources they own. As public interest in outdoor recreation continues to grow and land development accelerates, increased pressures will be put on 
Virginia's limited and fragile cave resources. The Virginia Cave Board is committed to safeguarding the unique educational, recreational, scientific, historic, and economic values of Virginia cave and karst areas. A board composed of concerned citizens, working in conjunction with other agencies of the commonwealth, appears to be the most effective vehicle for focusing the attention of both government and the public on this important conservation goal.

\section{REFERENCES}

Commonwealth of Virginia, Report of the Virginia Commission on the Conservation of Caves to the Governor and the General Assembly of Virginia, House Document No. 5, 1979, 48 p.
Collins, D., 1981, Battle of vandals, caves are losing: Washington Post, Section B, July 5 .

Department of Conservation and Economic Development, 1979, Virginia minerals: Division of Mineral Resources, Richmond, Virginia, v. 25, no. 4, p. 33-35.

Fagan, J.H., and Orndorff, W., 2002, Interagency cooperative sinkhole protection and karst remediation in Virginia, in Rea, T., ed., Proceedings of the National Cave and Karst Management Symposium, Tucson, Arizona, October 16-19, 2001, p. 101103.

Kramer, J.A., 2003, Preventing the destruction of America's cave resources: Enforcing cave protection legislation against vandals and profiteers: The Environmental Lawyer, v. 9, p. 725762.

Shetterly, M., 1983, Grottoes project funds blocked: Daily News-Record (Harrisonburg, Va.), p. 19-20, November 16.

Shetterly, M., 1984, Cave protection statue applied: Daily News-Record (Harrisonburg, Va.), p. 16, April 18. 